\title{
Sexually Transmitted Infections in Adolescents
}

\author{
Kazhila C. Chinsembu* \\ University of Namibia, Faculty of Science, Department of Biological Sciences, P/B 13301, Windhoek, Namibia
}

\begin{abstract}
Adolescents are the age group at greatest risk for nearly all Sexually Transmitted Infections (STIs). Adolescents are often at a higher risk for acquiring STIs because they are unable to conceptualize actions and their consequences. STIs are more prevalent among adolescent women than men, thus two thirds of newly infected adolescents aged 15-19 years are female. For reasons of biology, gender and cultural norms, adolescent females are also more susceptible than males to STIs. Biologically, adolescent women face increased anatomical and physiological susceptibility to infection due to increased cervical ectopy. The clinical presentation of STIs in adolescents should be carefully examined because some conditions are asymptomatic while other unrelated disease symptoms can easily be mistaken for STIs. This review presents some emergent epidemiological data from developed and developing countries that demonstrate the heavy burden of STIs on adolescents. However, more adolescent-specific STI studies are needed worldwide.
\end{abstract}

Keywords: Sexually transmitted infections, adolescents.

\section{INTRODUCTION}

Adolescence is the age range when persons are 10-19 years old [1]. Adolescents make up approximately $20 \%$ of the world's population; about $85 \%$ live in developing countries [2]. The definition of adolescents overlaps with that of the youth (aged 15-24 years) and young people (aged 10-24 years) [3].

The World Health Organization (WHO) estimates that each year, there are over 340 million new cases of curable bacterial and protozoal Sexually Transmitted Infections (STIs), namely those caused by Treponema pallidum, Neisseria gonorrhoeae, Chlamydia trachomatis and Trichomonas vaginalis, as well as many millions of persistent viral STIs, including some 5 million new Human Immunodeficiency Virus (HIV) infections, Human Herpes Viruses (HHV), Human Papilloma Viruses (HPV), and Herpes Simplex Viruses (HSV) [4]. STIs are spread primarily through person-to-person sexual contact [4]. STIs are a major worldwide public health concern and enigma [5]. Nearly a million people acquire an STI, including HIV, every day [4]. The annual occurrence of STIs, including HIV, accounts for the loss of more than 51 million years of healthy life among men, women and children worldwide [6]. In developing countries, STIs account for $17 \%$ of economic losses caused by ill-health [7]. In the United States of America (USA), annual health costs for STIs has reached US $\$ 17$ billion [8].

Adolescents are the age group at greatest risk for nearly all STIs [5]. One in 20 young people contracts a curable STI each year [1]. One out of four sexually active adolescent women is diagnosed with an STI every year $[5,9]$. The

\footnotetext{
*Address correspondence to this author at the University of Namibia, Faculty of Science, Department of Biological Sciences, P/B 13301, Windhoek, Namibia; Tel: +264-61-2063426; Fax: +264-61-2063791;

E-mail:kchinsembu2008@yahoo.co.uk
}

reasons for this trend are many, including cognitive development, physiologic susceptibility, peer pressure, logistic issues, and specific sexual behaviours [5].

In the USA, for example, 15 million people become infected with an STI each year $[10,11]$. Adolescents aged 15-19 years account for approximately 3 million cases, meaning one out of four sexually active teenager reports an STI every year $[8,11]$. This high prevalence will not only affect teens during adolescence, but also have an impact on their adult years through long-term sequelae, ectopic pregnancy, chronic abdominal pain, or infertility which can result from pelvic inflammatory disease (PID) [5]. Most STIs are sub-clinical and asymptomatic, making them a hidden epidemic [12].

STIs found in adolescents include gonorrhoea, Chlamydial infection, syphilis, trichomoniasis, chancroid, genital herpes, genital warts, HIV infection and hepatitis B infection [4]. Several STIs, in particular HIV and syphilis, can also be transmitted from mother to child during pregnancy and childbirth, and through blood products or tissue transfer [13].

There are more than 30 different sexually transmissible bacteria, viruses and parasites but only 19 of these are listed as the main causative agents of STIs [4]. Bacterial pathogens include Neisseria gonorrhoeae (causes gonorrhoea or gonococcal infection), Chlamydia trachomatis (causes Chlamydial infections), Treponema pallidum (causes syphilis), Haemophilus ducreyi (causes chancroid), and Klebsiella granulomatis (previously known as Calymmatobacterium granulomatis causes granuloma inguinale or donovanosis). Viral Sexually Transmitted Diseases (STDs) are caused by Human immunodeficiency virus (causes AIDS), HSV type 2 (causes genital herpes), HPV (causes genital warts and certain subtypes lead to cervical cancer in women), Hepatitis B virus (causes hepatitis and chronic cases may lead to cancer of the liver), HHV-8 causes Kaposis Sarcoma, and Cytomegalovirus 
(causes inflammation in a number of organs including the brain, the eye, and the bowel). Parasitic organisms include Trichomonas vaginalis (causes vaginal trichomoniasis), and Candida albicans which causes vulvovaginitis in women and inflammation of the glans penis and foreskin (balanoposthitis) in men [4].

\section{RISK FACTORS}

\section{Cultural and Socio-Economic Factors}

Two thirds of newly infected adolescents aged 15-19 in sub-Saharan Africa are female. Among women, the peak age for STI prevalence tends to be around age 25, 10 to 15 years younger than the peak age for men [2]. This is partly because sexually active adolescent women in Africa have partners 210 years their senior. STIs are usually the end-results of unprotected sex with a number of casual partners, but may also occur among those that have long-term unfaithful older partners or husbands. The risk of STIs is higher among adolescents that are poor and marginalized as they succumb to unprotected sex through coercion, force, violence and transactional reasons [2]. Some poor adolescent women engage in transactional sex, exchanging sex for money or gifts such as soap, perfume, meals, jewellery, school fees and help to their families [2]. Once in these relationships with teachers, drivers, shopkeepers or even policemen, girls have little power to negotiate the use of condoms.

\section{Cognitive Factors}

Cognitive development of adolescents may place them at increased risk of acquisition and transmission of STIs, as well as obstruct treatment and prevention efforts [5]. Adolescents are often at a higher risk for acquiring STIs because they are unable to conceptualize actions and their consequences thus many are unable to negotiate safer sex [5].

\section{Biological Factors}

Biologically, adolescent girls are at higher risk of contracting STIs. In adolescent girls, the cervix and vagina undergo dramatic histological changes due to estrogen exposure [12]. The epithelial lining of the vagina and cervix thicken and undergoes squamous metaplasia. The cervical columnar epithelium eventually recedes completely and is replaced by squamous epithelium. The replacement process is gradual and continues into adulthood. Hence the cervix in adolescent girls still displays areas of exposed columnar epithelium, a condition known as cervical ectopy [12]. Thus the cervix has an increased amount of ectropion (columnar epithelium that extrudes over the exocervix and into the vaginal vault) that makes adolescent girls more susceptible to gonorrhoea and Chlamydia $[14,15]$. Columnar epithelium is more vulnerable than squamous epithelium to infection by Chlamydia. Adolescent females are also at greater risk of HSV-2 infections [16].

\section{Sexual Behavior and Education}

Specific sexual behaviours such as early sexual activity (38\% of $9^{\text {th }}$ graders and $42 \%$ of $10^{\text {th }}$ graders in the USA have already tasted coitus), selection of older sexual partners, and inconsistent use of condoms increase adolescent susceptibility to STIs [5]. Other studies show that 55\% and $49 \%$ of USA adolescent males and females, respectively, were sexually active, with $19 \%$ of adolescent women reporting sexual debut at age 15 in 1995 [17]. Some $29 \%$ of USA adolescent men and $19 \%$ of adolescent women did not use condoms in their most recent sexual intercourse [17]. Most adolescents do not accurately perceive their susceptibility to STIs. For example, $81 \%$ of adolescent women diagnosed with gonorrhoea had perceived themselves to be at little or no risk of STIs [18]. Adolescents may also have inaccurate information regarding STIs.

A high prevalence of sexual intercourse was also observed among school-going adolescents in Namibia [19]. Using data from the Namibia Global School-Based Health Survey 2004, the overall prevalence of sexual intercourse in the preceding 12 months was 33.1\% (43.9\% males and $25.4 \%$ females). Sexual intercourse was higher among school-going adolescents that smoked cigarettes, drank alcohol, and used drugs. Parental supervision was negatively associated with sexual intercourse [19]. Sexual activity in Namibia begins at a very young age, often as low as 10 years. Data obtained from a cross-sectional survey conducted among adolescents aged 12-18 years, of median age 15 years, living in school-based hostels in Namibia, showed that $56 \%$ of the boys had already experienced sexual intercourse [20]. Among those that were sexually experienced, 29\% had more than one sex partner in the preceding six months, and only 50\% used a condom during their most recent intercourse [20]. Adolescents are more vulnerable to STIs because of a lack of sex education, yet in some instances, sex education in schools begins late when adolescents have already been initiated into sexual intercourse.

\section{Limited Success of Preventive and Treatment Services}

The higher prevalence of STIs among adolescents could be attributed to the many barriers to adolescent-sensitive STI prevention services, including non-compliant treatment seeking behaviours driven by the lack of health insurance or other inabilities to pay, lack of transportation to STI clinics, embarrassment with facilities and services designed for adults, and apprehensions about confidentiality [21]. Customized STI service delivery for adolescents is often lacking, and even in developed countries, many adolescents that have contracted STIs are still unreached [22-24].

\section{Demographic and Ecological Factors}

Demographic and ecological variables (e.g. poor neighbourhoods) put certain groups of adolescents at greater risk of STIs, especially minorities, gay, lesbian and transgender youth, drug users (particularly parenteral), homeless, runaways, commercial sex workers, and pregnant or incarcerated (jailed) youths [21].

\section{Co-Infection with HIV}

The presence of syphilis, chancroid ulcers or genital herpes simplex virus infection greatly increases the risk of acquiring or transmitting HIV. This was more so after evidence from Mwanza, Tanzania, showed that rigorous syndromic management of STIs reduced new HIV infections by $40 \%$ [25]. These results demonstrated that STIs account for $40 \%$ of new HIV infections, hence STI treatment is an important strategy in the prevention of AIDS, especially in sub-Saharan Africa where $25 \%$ of adolescent girls are infected by HIV [26]. Bacterial vaginosis and physico- 
chemical disturbances of the vaginal flora also increases acquisition of HIV [26].

\section{EPIDEMIOLOGICAL EVIDENCE}

There are overwhelming epidemiological data that demonstrate the heavy burden of STIs on adolescents. In 2007, WHO estimated that a third of the 333 million cases of curable STIs occurred among young people under the age of 25 [4]. The highest infection rates are in 20-24 year olds, followed by adolescents aged 15-19 years. Young people were also more likely than adults to be re-infected after having been treated $[2,4,5]$. More than $40 \%$ of adolescents are subsequently infected by at least one STI other than the initial infecting organism [27].

Adolescents and young people make up only $25 \%$ of the sexually active population but represent almost $50 \%$ of all new STIs [28]. About $60 \%$ of adolescent patients with one STI are concurrently infected with another [29], and new STIs are still detected in adolescents with low and high viral loads of HIV [30]. C. trachomatis is the most common cause of STDs worldwide, with highest infection rates among females aged 15-24 years [14]. One third of all $C$. trachomatis cases worldwide occur among adolescents [11]. Chlamydia has received significant attention as the most common bacterial STI and the primary aetiological culprit for epididymitis in males, PID, tubal infertility, and ectopic pregnancy in females [31].

The World Health Organization, United Nations Development Programme (UNDP) and the World Bank currently sponsor a program called the Sexually Transmitted Disease Diagnostics Initiative (SDI) [32]. The SDI was founded in 1990 in response to a widely-perceived need to improve care for patients with STIs in resource-limited settings through improved diagnostics. The SDI secretariat had been housed in various agencies since its inception and has most recently moved from UNAIDS to the WHO, where it is managed out of the Special Program for Research and Training in Tropical Diseases [32].

\section{Developed Countries}

Estimates indicate that 30 million curable STIs (syphilis, gonorrhoeae, Chlamydia and trichomoniasis) occurred every year in North America and Western Europe in the mid-1990s [33]. In an extensive review by Panchaud and others [33], $31 \%$ of USA adolescents had Chlamydia and gonorrhoeae in 1996; 24\% of adolescents in Canada had gonorrhoeae in 1996; and 18\% of adolescents in the Russian Federation had syphilis in 1994. The incidence of syphilis was 2-3 times higher among female adolescents than male adolescents in Canada, Finland, the Russian Federation and the USA [33].

The bulky of age-specific epidemiological data on STIs in adolescents are from the USA where widespread screening and reporting are undertaken by the Centres for Disease Control and Prevention (CDC). Table 1 shows the epidemiological burden of STIs in the USA. About 15 million cases of STIs occur annually in the USA, nearly 4 million among adolescents [34]; a quarter of STIs are found in adolescents aged 15-19 years [35]. As many as $26 \%$ of adolescent girls in the USA may be infected with at least one STD, according to a CDC study presented at the 2008
National STD Prevention Conference [36]. The STD prevalence among girls who reported three or more lifetime sex partners was approximately $50 \%$. After controlling for sexual behavior, black girls were more than three times as likely to contract an STD compared with white girls. In this study, $48 \%$ of black girls had at least one STD compared with $20 \%$ of adolescent white girls. The two most common STDs among adolescent girls were HPV and Chlamydia. Approximately $18 \%$ of girls had HPV and $4 \%$ had Chlamydia. The CDC recommends annual Chlamydia screening for sexually active women aged 25 and younger. The CDC also recommends that girls and women aged between 11 and 26 years who have not been vaccinated or who have not completed the full series of shots be fully vaccinated against $\mathrm{HPV}$.

Genital C. trachomatis infection is one of the most prevalent STIs in the USA, with a $43.5 \%$ infection rate in the general population, and a 3: 1 ratio among women and men [28]. In adolescents, Chlamydia is more prevalent than gonorrhoea [37]. Chlamydia rates among USA adolescents are 20 times higher than among adolescents in France, five times higher than in England and Wales, and twice as high as in Canada [33]. African-American females and males aged 15-19 years were seven times and 12 times more likely to have Chlamydia than their white counterparts, respectively [38]. In Australian adolescents sampled from High Schools around Brisbane, the overall prevalence of C. trachomatis infection among adolescents was low; a finding that differed significantly from Chlamydia rates found in adolescents detached from formal schooling [31]. In western countries, adolescent females under the age of 20 are most susceptible to $C$. trachomatis [39]. Females under the age of 20 are more likely to be infected by C. trachomatis [39].

Gonorrhoea is the second most commonly reported STI in the USA with about 600,000 new cases as of 2004 [40]; this case load has come down to about 350,000 annual cases as of $2008 ; 30 \%$ of which involve $15-19$ year olds [14]. While the overall USA rate of gonorrhoea was 129 per 100,000 in the general population, the rate among adolescent women aged 15-19 years was 703 per 100,000 [38]. Gonorrhoea rate among USA adolescents is 74 times higher than the rate in the Netherlands and France, 10 times higher than in Canada, and seven times higher than in England and Wales [33]. Overall, $75 \%$ of all USA reported gonorrhoea cases were in African-Americans (782 per 100,000 population) [38]. Gonorrhea rates among 15-19 year-old whites were highest in the South; 325.0 cases per 100,000 population for white females and 124.4 cases per 100,000 population for white males [41]. Despite the fact that overall incidence of gonorrhoea has declined in the USA, the disease is now highest among 10-14 year olds [42].

From 1981-91, 24-30\% of the reported morbidity from gonorrhea and $10-12 \%$ of the reported morbidity from primary and secondary syphilis in the USA were from the adolescent age groups [21]. Over the 10-year period, gonorrhoea rates decreased among all age and sex groups except 10-14 year-old males (41\%), 10-14 year-old females (51.2\%), and 15-19 year-old males (1.6\%) [21]. In 1991, some of the highest rates of gonorrhoea were among 15-19 year-olds; 882.6 cases per 100,000 population for males and 
Table 1. Epidemiological Burden of STIs in the United States

\begin{tabular}{|c|c|c|c|c|}
\hline STD/Aetiological Agent & Age Group & Infection Rate & Year/Years of Study & References \\
\hline Human Papillomavirus & All adolescents, $14-19$ years & $35 \%$ & 2000 & {$[74]$} \\
\hline Human Papillomavirus & Adolescent females, 14-19 years & $18 \%$ & $2003 / 04$ & [75] \\
\hline Human Papillomavirus & $\begin{array}{l}\text { Adolescent females that reported } \\
\text { sexual intercourse }\end{array}$ & $30 \%$ & 1999 & {$[76]$} \\
\hline Chlamydia & $\begin{array}{l}\text { Adolescent females that reported } \\
\text { sexual intercourse }\end{array}$ & $7 \%$ & 1999 & [76] \\
\hline Chlamydia & Adolescent females, 15-19 years & $2,796.6$ cases per 100,000 persons & 2003 & {$[77]$} \\
\hline Chlamydia & Adolescent females, 15-19 years & 2,536 cases per 100,000 persons & 2001 & {$[38]$} \\
\hline Chlamydia & Adolescent females, 15-19 years & 2,483 cases per 100,000 persons & 1999 & {$[78]$} \\
\hline Chlamydia & Adolescent males, $15-19$ years & 376 cases per 100,000 persons & 2001 & {$[38]$} \\
\hline Chlamydia & $\begin{array}{l}\text { Non-adolescent young men, 20-24 } \\
\text { years }\end{array}$ & 2,691 cases 100,000 persons & 2003 & {$[77]$} \\
\hline Chlamydia & Adolescent males, $15-19$ years & 344 cases per 100,000 persons & 1999 & {$[78]$} \\
\hline Chlamydia & Adolescent females, 10-19 years & $29.1 \%$ & 1998 & {$[79]$} \\
\hline Chlamydia/gonorrhoeae & All adolescents, $10-19$ years & $31 \%$ & 1996 & {$[33]$} \\
\hline Gonorrhoea & Adolescent females, $15-19$ years & $\begin{array}{l}624.7 \text { cases per } 100,000 \text { adolescent } \\
\text { females aged } 15-19 \text { years }\end{array}$ & 2000 & [74] \\
\hline Gonorrhoea & Adolescent females, 10-14 years & $\begin{array}{l}35.1 \text { cases per } 100,000 \text { females aged } \\
10-14 \text { years }\end{array}$ & 2006 & {$[80]$} \\
\hline Gonorrhoea & Adolescent females, 15-19 years & $\begin{array}{c}625 \text { cases per } 100,000 \text { females aged } \\
15-19 \text { years }\end{array}$ & 2006 & {$[80]$} \\
\hline Gonorrhoea & Adolescent females, $15-19$ years & $\begin{array}{c}703 \text { cases per } 100,00 \text { females aged } \\
15-19 \text { years }\end{array}$ & 2001 & [38] \\
\hline Gonorrhoea & Adolescent males, $10-14$ years & $41 \%$ & 1981-91 & [21] \\
\hline Gonorrhoea & Adolescent females, $10-14$ years & $51.2 \%$ & 1981-91 & [21] \\
\hline Gonorrhoea & Adolescent females, $15-19$ years & $\begin{array}{c}1,043.6 \text { cases per } 100,000 \text { population } \\
\text { of females }\end{array}$ & 1991 & {$[33]$} \\
\hline $\begin{array}{l}\text { Primary and secondary } \\
\text { syphilis }\end{array}$ & All adolescents, 10-19 years & $10-12 \%$ & 1981-91 & [41] \\
\hline Herpes Simplex Virus type 2 & All adolescents, $10-19$ years & $5.6 \%$ seroprevalence rate & 1976-94 & [81] \\
\hline Herpes Simplex Virus type 2 & All adolescents, $10-19$ years & $12 \%$ seroprevalence & 1997 & [82] \\
\hline Trichomonas vaginalis & Adolescent girls, 10-19 years & $14 \%$ & unspecified & {$[15]$} \\
\hline
\end{tabular}

1,043.6 cases per 100,000 population for females, respectively [33]. In the United Kingdom (UK), gonorrhoea cases increased by $8 \%$ in males and $10 \%$ in females; among females, $40 \%$ of the cases were in adolescent girls [43]. Chlamydial and gonorrhoea infections are often transmitted together, and are usually asymptomatic [14]. Up to $84 \%$ of adolescent men infected with $N$. gonorrhoeae had no symptoms [14].

At least 50 million people in the USA have genital herpes simplex infection with one million new cases of HSV-2 diagnosed each year [44]. HSV infection results from exposure to infected oral or genital secretions. Both HSV-1 and HSV-2 are capable of causing oral or genital infection. However, almost all oral infections are caused by HSV-1. HSV-2 is almost exclusively sexually transmitted, hence its sero-detection is indicative of having acquired genital HSV2 infection. HSV-2 seroprevalence in adolescents has been reported in several studies, see Fig. (1). An 80\% increase in the number of new cases of genital herpes were recorded in the decade leading to 2004 in the UK, with $17 \%$ of all primary HSV infections occurring in adolescent girls below 19 years [45].

\section{Developing Countries}

It is estimated that $80-90 \%$ of the global burden of STIs occurs in the developing world where there is limited or no access to diagnostics [4]. In particular, there is an urgent need for improved diagnostics for STIs in HIV endemic areas as studies in sub-Saharan Africa have shown that STIs are important cofactors in the transmission of HIV infection. The issues of concern for treating and preventing STIs are similar to those for HIV/AIDS. The focus of international discussion should remain focussed around three themes: (1) access to treatment, (2) increasing healthcare personnel to treat and test for STIs to reduce the risk of complications 
from untreated infections, and (3) continued commitment on the part of member states to finance treatment and prevention programs sponsored by the World Health Organization.

Research on STIs of adolescents in developing countries is confronted by two basic methodological challenges. First, there is paucity of comprehensive age and sex-specific data on STIs (excluding HIV). Thus the true scale of the epidemiological burden of STIs among adolescents is not known because most surveys are done at specific health services such as family planning and antenatal clinics where adolescents are under-represented. Epidemiological surveys to determine prevalence of STIs among out-of-school adolescents are also lacking. Generally, STIs are more prevalent among African and Caribbean adolescents than in other regions of the world, partly because sexual debut comes as early as 10-11 years in some African and Caribbean countries [19]. Studies on gonorrhoea in selected Middle East and African countries found STI levels were highest among 15-19 year olds [46].

Second, the prevalence of STIs among adolescent boys has not been widely reported. This may be due to nontreatment seeking behaviour, or may partly reflect the lower disease burden in this group. A few studies [47, 48] report STI infections in males but do not mark out those for adolescents. But many adolescent boys in studies from Argentina, Botswana, Peru, the Phillipines, the Republic of Korea and Thailand have experienced symptoms of STIs [49]. Notwithstanding, there are a few age and sex-specific data on STIs other than HIV. Table 2 shows the epidemiological burden of STIs in some developing countries. In Dhaka, Bangladeshi, the prevalence of STIs in 13 to 18 -year old hotel-based female sex workers was $6.6 \%$ [50]. In Bangladeshi adolescents under the age of 15 years, no males reported having had an STI but $2.9 \%$ of females reported an STI in the past 12 months in the 15-19-year age group [50]. This low prevalence of STIs in Bangladeshi could be due to religious and cultural beliefs.

In South Africa, adolescent girls were 30\% more likely to get STIs than their male counterparts, partly because of their older male partners who are more likely to have STIs [51]. In KwaZulu Natal, two-thirds of abused adolescents had one or more STIs [52]. In Younde, Cameron, overall rates of STIs among adolescent boys ranged from $15-25 \%$ in the year 2000 and $14-18 \%$ in 2002 [53]. The burden of STIs among adolescent girls was notably higher, averaging $46-55 \%$ in the year 2000 and $34-36 \%$ in 2002 [53]. Such higher rates among adolescent girls raise the question whether STIs were lumped together with non-sexually transmitted reproductive tract infections [53].

In Dar es Salaam, Tanzania, the burden of STIs in the general adolescent population was high, especially for genital discharge and candidiasis [54]. More adolescent females (20.8\%) were HIV infected than males (11.5\%) [55]. There was a tendency towards genital ulcerative disease in HIV-infected than non-infected adolescents, 27 vs 19\% in males, and 49 vs $23 \%$ in females, respectively [55]. In the Central African Republic, there is at least one STI in 34\% of antenatal clinic attendees aged 14-22 years [56], with about
$12 \%$ of those with STIs being HIV-positive. Almost a quarter of pregnant adolescents aged 15-19 years in Tanzania had Trichomonas vaginalis which places young adolescents at increased risk of contracting HIV [57].

Chlamydia is considered an adolescent infection, and its presence is a marker of recent onset of sexual activity. In Jamaica and the Democratic Republic of Congo, almost 50\% of adolescents at high risk of STIs may have either gonorrhoea or Chlamydia or both [58, 59], respectively. However, in most developing cpuntries, the prevalence of gonorrhoea is lower than Chlamydia, often below 10\% [2] with a slight exception in Namibia where $11 \%$ of adolescent girls presented with gonorrhoea in 1998 [60]. In 2002, 4.1\% of Namibian adolescent males and $4.5 \%$ of adolescent females self-reported STIs [61]. Of these, 3.9\% of male adolescents and $6.3 \%$ of female adolescents indicated that they had genital discharge, while $3.6 \%$ of males and $3 \%$ of females had genital ulcers or sores [61]. Syphilis was reported among $5 \%$ of Namibian adolescents. The prevalence of gonorrhoea was low: $<5 \%$ in Nigerian and Senegalese adolescents that live in villages, and about $6 \%$ in Kenyan adolescents attending Family Planning and antenatal clinics [2]. Adolescent sex workers were 2.5 times more likely to have cervicitis although it could not be attributed to gonorrhoea or Chlamydia [62]. STI prevalence in Brazilian adolescents was $2 \%$ for gonorrhea [63], and $5-20 \%$ for Chlamydia [63-65].

Fig. (1) compares HSV-2 seroprevalence rates in developed and developing countries. The results show that the seroprevalence of HSV-2 is significantly higher in less developed countries (Uganda and Tanzania) than in the developed world (Spain and Sweden).

\section{CLINICAL SYMPTOMS}

The clinical presentation of STIs in adolescents is peculiar because various other symptoms can be mistaken for STIs [66]. In girls, endogenous vaginitis rather than an STI is the main cause of vaginal discharge among adolescent females. However, there may be vulval itching, minor discharge, urethritis or proctitis. In pre-pubescent girls, a purulent vulvo-vaginitis may occur. Similarly, C. trachomatis infection is asymptomatic in the majority of adolescent girls. Symptoms that may occur in the adolescent woman are inter-menstrual bleeding, post-coital bleeding and an increase in vaginal secretions [4].

C. albicans is uncommon in adolescent women prior to puberty. If present, the adolescent may have a discharge, vulval itching, dyspareunia, peri-anal soreness or a fissuring at the introitus $[4,66]$. Attacks of candida vulvitis may be cyclical in nature and corresponds to menstruation [4]. Bacterial vaginosis does not produce vulvitis and the adolescent girl will not complain of itching or soreness [4]. The signs of acquired syphilis in children present with small chancres or mucocutaneous moist lesions either on the vulva or anus. Presentation of syphilis is the same in adolescent girls and adults [4]. In adolescent boys, gonorrhea presents as proctitis, urethral discharge, asymptomatic pyuria, penile edema, epididyimitis and testicular swelling. Disseminated gonorrhoea presents with multiple systemic manifestations. Chlamydia in adolescent males presents as urethritis [4]. 
Table 2. Epidemiological Burden of STIs in Some Developing Countries

\begin{tabular}{|c|c|c|c|c|}
\hline Country & STD/Aetiological Agent & Age Group & Infection Rate & Year of Study - Reference \\
\hline Tanzania & Genital discharge & Adolescents, 10-19 years & $\begin{array}{l}54 \% \text { in males; } 63 \% \\
\text { in females }\end{array}$ & $2006[54]$ \\
\hline Tanzania & Candidiasis & Adolescent women, 10-19 years & $27 \%$ & $2006[54]$ \\
\hline Tanzania & Bacterial vaginosis & Adolescent women, 10-19 years & $17 \%$ & $2006[54]$ \\
\hline Tanzania & Trichomoniasis & Adolescent women, 10-19 years & $11 \%$ & $2006[54]$ \\
\hline Tanzania & Trachomatis vaginalis & $\begin{array}{c}\text { Pregnant adolescents, } 15-19 \\
\text { years }\end{array}$ & $25 \%$ & $1996[57]$ \\
\hline Tanzania & Chlamydia trachomatis & Adolescent men, $10-19$ years & $10 \%$ & $2006[54]$ \\
\hline Tanzania & Genital warts & All adolescents, $10-19$ years & $3.3 \%$ & $2008[55]$ \\
\hline Tanzania & Genital ulcer disease & All adolescents, 10-19 years & $14 \%$ & $2008[55]$ \\
\hline Tanzania & Herpes Simplex Virus type 2 & $\begin{array}{l}\text { Adolescent women in rural } \\
\text { areas, } 15-19 \text { years }\end{array}$ & $43 \%$ seroprevalence & 1999 [83] \\
\hline Tanzania & Herpes Simplex Virus type 2 & $\begin{array}{c}\text { Adolescent men in rural areas, } \\
15-19 \text { years }\end{array}$ & $20 \%$ seroprevalence & 1999 [83] \\
\hline Central African Republic & Gonorrhoea & $\begin{array}{l}\text { 14-22 year old antenatal clinic } \\
\text { attendees }\end{array}$ & $3.1 \%$ & $1999[56]$ \\
\hline Central African Republic & Chlamydia & $\begin{array}{l}\text { 14-22 year old antenatal clinic } \\
\text { attendees }\end{array}$ & $6.2 \%$ & $1999[56]$ \\
\hline Central African Republic & Syphilis & $\begin{array}{l}\text { 14-22 year old antenatal clinic } \\
\text { attendees }\end{array}$ & $7 \%$ & $1999[56]$ \\
\hline Central African Republic & Bacterial vaginosis & $\begin{array}{l}\text { 14-22 year old antenatal clinic } \\
\text { attendees }\end{array}$ & $29 \%$ & $1999[56]$ \\
\hline Central African Republic & Candidiasis & $\begin{array}{l}\text { 14-22 year old antenatal clinic } \\
\text { attendees }\end{array}$ & $47 \%$ & $1999[56]$ \\
\hline Uganda & Chlamydia & Adolescent men, $10-19$ years & $26 \%$ & 1994 [84] \\
\hline Uganda & Chlamydia & $\begin{array}{l}\text { Adolescent women in village } \\
\text { surveys, } 10-19 \text { years }\end{array}$ & $6 \%$ & $1996[39,45]$ \\
\hline Uganda & Chlamydia & $\begin{array}{l}\text { Adolescent women, antenatal } \\
\text { clinic attendees, } 10-19 \text { years }\end{array}$ & $10-20 \%$ & $1995[2]$ \\
\hline Uganda & Herpes Simplex Virus type 2 & All adolescents, $15-19$ years & $34 \%$ seroprevalence & 1994 [84] \\
\hline Uganda & Herpes Simplex Virus type 2 & $\begin{array}{l}\text { Adolescent women in rural } \\
\text { areas, } 15-19 \text { years }\end{array}$ & $27 \%$ seroprevalence & 1994 [84] \\
\hline Uganda & Herpes Simplex Virus type 2 & $\begin{array}{c}\text { Adolescent men in rural areas, } \\
15-19 \text { years }\end{array}$ & $7.5 \%$ seroprevalence & 1994 [84] \\
\hline Senegal & Chlamydia & $\begin{array}{l}\text { Adolescent women, sex workers, } \\
10-19 \text { years }\end{array}$ & $>40 \%$ & $1995[2]$ \\
\hline Nicaragua & Chlamydia & $\begin{array}{l}\text { Adolescent women, antenatal } \\
\text { clinic attendees, } 10-19 \text { years }\end{array}$ & $6 \%$ & unclear [2] \\
\hline Nigeria & Chlamydia & $\begin{array}{l}\text { Adolescent women in village } \\
\text { surveys, } 10-19 \text { years }\end{array}$ & $10 \%$ & $1996[39,45]$ \\
\hline Nigeria & Genital warts & Adolescent women, 10-19 years & $2 \%$ & 1998 [85] \\
\hline Nigeria & Trichomonas vaginalis & All adolescents, 15-19 years & $25 \%$ & $1995[2]$ \\
\hline Thailand & Chlamydia & $\begin{array}{l}\text { Adolescent women, antenatal } \\
\text { clinic attendees, } 10-19 \text { years }\end{array}$ & $12 \%$ & unclear [2] \\
\hline Brazil & Chlamydia & Adolescent women, 15-19 years & $9 \%$ & 2004 [63] \\
\hline Brazil & Gonorrhoea & Adolescent women, 15-19 years & $2 \%$ & $2004[63]$ \\
\hline Brazil & Chlamydia & $\begin{array}{l}\text { Adolescent women+ young } \\
\text { women }\end{array}$ & $20 \%$ & $2006[65]$ \\
\hline Brazil & Chlamydia & $\begin{array}{l}\text { Adolescent men, asymptomatic } \\
\text { military conscripts }\end{array}$ & $5 \%$ & 2005 [64] \\
\hline Zambia & $\begin{array}{l}\text { Penile discharge caused by } \\
\text { Chlamydia or gonorrhoea }\end{array}$ & Adolescent men, $10-19$ years & $3.3 \%$ & $1996[86]$ \\
\hline
\end{tabular}




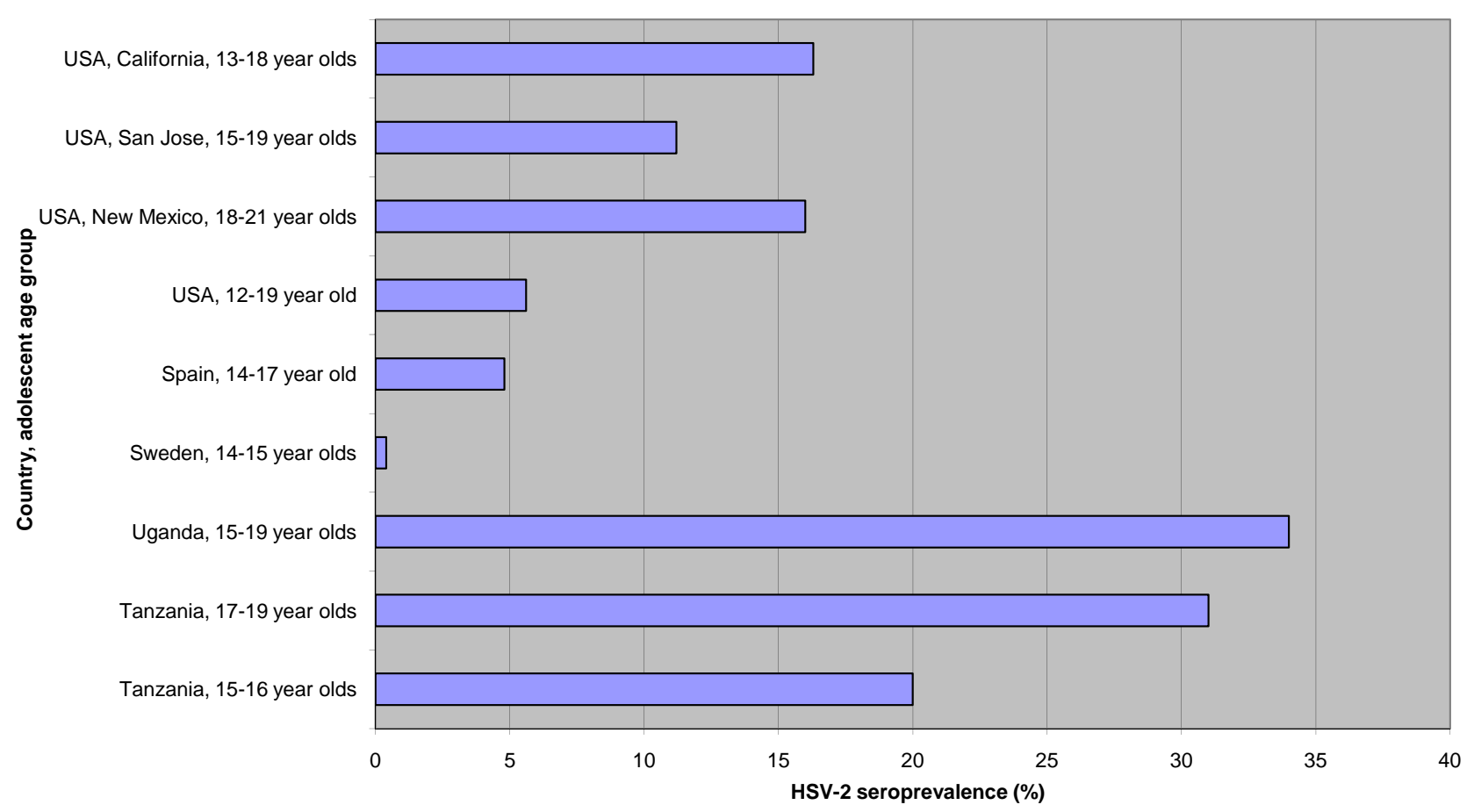

Fig. (1). HSV-2 seroprevalence in adolescents from different settings.

Some STIs usually exist without symptoms. For example, aapproximately $85 \%$ of gonococcal infections in females will be asymptomatic, and up to $70 \%$ of women and a significant proportion of men with gonococcal and/or Chlamydial infections may experience no symptoms at all [4]. Both symptomatic and asymptomatic infections can lead to the development of serious complications and sequelae [4]. Non-treatment of Chlamydia results in long-range sequalae such as PID, ectopic pregnancy and infertility [2]. PID was found in $15 \%$ of adolescents with untreated Chlamydia [67], and adolescence was highly associated with recurrent PID in the USA [68].

STIs are a bigger problem in pregnant adolescents where they cause more miscarriages than in older pregnant women [69]. In Malawi, for example, $52.3 \%$ of all nulliparae at antenatal clinics were adolescents, $25 \%$ were 16 years or younger, of which $4.5 \%$ were VDRL-positive [69]. Untreated syphilis in adolescent girls causes $25 \%$ of pregnancies to result in stillbirth and $14 \%$ in neonatal death, and an overall perinatal mortality of about $40 \%$ [4]. Approximately $35 \%$ of pregnancies among women with untreated gonococcal infection result in spontaneous abortions and premature deliveries, and up to $10 \%$ in perinatal deaths [4]. In the absence of prophylaxis, 30-50\% of infants born to adolescent mothers with untreated gonorrhoea and up to $30 \%$ of infants born to adolescent mothers with untreated Chlamydial infection develop ophthalmia neonatorum, a condition that can lead to blindness if untreated [4]. Many asymptomatic adolescents are unaware of their being infected, and in addition to not seeking treatment, this 'silent reservoir' continues to spread STIs in the general adolescent population.

\section{MANAGEMENT OF STIS IN ADOLESCENTS}

Management of STIs is a major challenge in many countries because of the emergency of drug resistant strains of STIs and HIV. Drug resistance has contributed to many cases of STI treatment failures, besides making STI treatment more expensive [70]. Although effective STI patient management is the cornerstone of STI control, management of STIs remains one of the greatest challenges in health care delivery especially in developing countries. Several factors have contributed to the problem of STI management: stigma, societal attitudes towards sex, inadequate resources, high levels of drug resistance, lack of diagnostic facilities, and lack of trained person-power [71]. The key steps in the management of STI patients are: making the correct diagnosis, prescribing the correct and effective treatment, and equipping the patient with information to promote safer sex and personal prophylaxis through counseling, contact tracing, and condom promotion [71]. Traditionally, management of STIs is based on laboratory diagnosis and prescription of treatment tailored to the etiological diagnosis. This has remained the benchmark of medical practice for ages. However, due to non-availability of laboratory equipment in some settings, coupled with the time-lag in waiting for laboratory results, patients have to be managed by covering the common causes of the particular disease. This approach is now known as syndromic STI management where the diagnosis is based on a combination of symptoms and signs which the patient presents [71]. There are several advantages and disadvantages of both etiological and syndromic management but regardless of the approach, the management of STIs in adolescents should be based on the these principles: confidentiality; correct 
diagnosis; correct drug, dosage and route; counseling; compliance; contact tracing; condom promotion; and clinical follow-up [71].

\section{Treatment}

Drugs for STI treatment should meet the following criteria: high efficacy, low cost, low toxicity, preferably single dose, given by oral administration, low or no resistance to target organism, and not contraindicated in pregnant women [12]. Practitioners recommend that since compliance can be a serious drawback among adolescents, single-dose therapy should be used whenever possible [5]. Further, practitioners should be sure that their adolescent patients understand the need to abstain from sexual intercourse for at least 7 days following the completion of their therapy. It is recommended that patients with gonococcal infections be treated for Chlamydia as well, because of a coinfection in one third of cases of gonorrhoea. Dual treatment of co-infected adolescents is encouraged as it may reduce the development of resistant strains [72]; 30\% of $N$. gonorrhoeae isolates were resistant to penicillin, tretracycline, or both [73]. On the other hand, syndromic management of $C$. trachomatis infection could be inadequate because this infection produces few or no symptoms at all in the majority of women and men. There are recommended and alternative regimens for treatment of STI organisms and syndromes as shown in Tables $\mathbf{3}$ and $\mathbf{4}$.

Table 3. Treatment of STIs, by Commonly Transmitted Organisms

\begin{tabular}{|c|c|c|}
\hline Infection & Recommended Regimens & Alternative Regimens \\
\hline Chlamydia trachomatis & $\begin{array}{l}\text { Azithromycin } 1 \mathrm{~g} \text { PO single dose or } \\
\text { Doxycycline } 100 \mathrm{mg} \text { PO } 2 \mathrm{x} / \mathrm{d} \text { for } 7 \text { days }\end{array}$ & $\begin{array}{l}\text { Erythromycin base } 500 \mathrm{mg} \text { PO } 4 \mathrm{x} / \mathrm{d} \text { for } 7 \\
\text { days or } \\
\text { Erythromycin ethylsuccinate } 800 \mathrm{mg} \text { PO } \\
4 \mathrm{x} / \mathrm{d} \text { for } 7 \text { days } \\
\text { or } \\
\text { Ofloxacin } 300 \mathrm{mg} \text { PO } 2 \mathrm{x} / \mathrm{d} \text { for } 7 \text { days }\end{array}$ \\
\hline \multicolumn{3}{|l|}{ Neisseria gonorrhoeae } \\
\hline Uncomplicated cervical, urethral, or rectal & $\begin{array}{l}\text { Cefixime } 400 \mathrm{mg} \text { PO single dose or } \\
\text { Ceftriaxone } 125 \mathrm{mg} \text { IM single dose or } \\
\text { Ofloxacin } 400 \mathrm{mg} \text { single dose }+ \text { Azithromycin } 1 \mathrm{~g} \text { PO } \\
\text { single dose or } \\
\text { Doxycycline } 100 \mathrm{mg} \text { PO } 2 \mathrm{x} / \mathrm{d} \text { for } 7 \text { days }\end{array}$ & $\begin{array}{l}\text { Erythromycin base } 500 \mathrm{mg} \text { PO } 4 \mathrm{x} / \mathrm{d} \text { for } 7 \\
\text { days or } \\
\text { Erythromycin ethylsuccinate } 800 \mathrm{mg} \text { PO or } \\
\text { May be substituted for azithromycin or } \\
\text { doxycycline }\end{array}$ \\
\hline Pharyngeal & $\begin{array}{l}\text { Ceftriaxone } 125 \mathrm{mg} \text { IM single dose or } \\
\text { Ciprofloxacin } 500 \mathrm{mg} \text { PO single dose or } \\
\text { Ofloxacin } 400 \mathrm{mg} \text { PO single dose }+ \text { Azithromycin } 1 \mathrm{~g} \\
\text { PO single dose or } \\
\text { Doxycycline } 100 \mathrm{mg} \text { PO } 2 \mathrm{x} / \text { day for } 7 \text { days }\end{array}$ & None \\
\hline $\begin{array}{l}\text { Syphilis } \\
\text { No penicillin allergy, Early syphilis; }\end{array}$ & $\begin{array}{l}\text { Procaine Penicillin } 1.2 \text { megaunit imi for } 10 \text { days or } \\
\text { Benzathine Penicillin } 2.4 \text { megaunit imi for } 3 \text { weeks } \\
\text { Procaine Penicillin } 1.2 \text { megaunit and Probenecid } \\
500 \mathrm{mg} \text { for } 15 \text { days }\end{array}$ & $\begin{array}{l}\text { Tetracycline } 500 \mathrm{mg} \text { orally } 4 \mathrm{x} / \mathrm{d} \text { for } 25 \text { days } \\
\text { or } \\
\text { Erythromycin } 500 \mathrm{mg} \text { orally } 4 \mathrm{x} / \mathrm{d} \text { for } 15 \\
\text { days }\end{array}$ \\
\hline $\begin{array}{l}\text { No penicillin allergy, Late latent syphilis } \\
\text { Penicillin allergy }\end{array}$ & $\begin{array}{l}\text { Doxycycline } 100 \mathrm{mg} \text { bd for } 2 \text { weeks for early syphilis, } \\
\text { and } 4 \text { weeks for late syphilis, respectively }\end{array}$ & \\
\hline Chancroid & Erythromycic $500 \mathrm{mg}$ orally $4 \mathrm{x} / \mathrm{d}$ for 7 days & None \\
\hline Candidiasis & $\begin{array}{l}\text { Nystatin } 1000 \text { IU intravaginally daily for } 14 \text { days or } \\
\text { Miconazole } 200 \mathrm{mg} \text { intravaginally daily for } 3 \text { days }\end{array}$ & None \\
\hline $\begin{array}{l}\text { Genital herpes infections } \\
\text { Primary first episode }\end{array}$ & $\begin{array}{l}\text { Acyclovir } 200 \mathrm{mg} \text { Orally } 5 \mathrm{x} / \mathrm{d} \text { for } 5 \text { days or } \\
\text { Famciclovir } 250 \mathrm{mg} \text { tds for } 5 \text { days } \\
\text { Valaciclovir } 500 \mathrm{mg} \text { bd for } 5 \text { days }\end{array}$ & None \\
\hline Frequent and recurrent episodes & $\begin{array}{l}\text { Prophylactic continuous antiviral therapies: Acyclovir } \\
400 \mathrm{mg} \text { bd for } 6-12 \text { months; then assess disease activity }\end{array}$ & None \\
\hline Trichomoniasis & $\begin{array}{l}\text { Metronidazole } 2 \mathrm{~g} \text { PO single dose or } \\
\text { Metronidazole } 500 \mathrm{mg} \text { PO } 2 \mathrm{x} / \mathrm{d} \text { for } 7 \text { days }\end{array}$ & None \\
\hline
\end{tabular}


Table 4. Treatment of STIs, by Common Syndromes

\begin{tabular}{|c|c|c|}
\hline Urethritis & $\begin{array}{l}\text { Cefixime } 400 \mathrm{mg} \text { PO single dose or } \\
\text { Ceftriaxone } 125 \mathrm{mg} \text { IM single dose or } \\
\text { Ofloxacin } 1 \mathrm{~g} \text { PO single dose }+ \text { Azithromycin } 1 \mathrm{~g} \text { PO single dose or } \\
\text { Doxycycline } 100 \mathrm{mg} \text { PO } 2 \mathrm{x} / \mathrm{d} \text { for } 7 \text { days }\end{array}$ & None \\
\hline Recurrent/persistent urethritis & $\begin{array}{l}\text { Metronidazole } 2 \mathrm{~g} \text { PO single dose }+ \text { Erythromycin base } 500 \mathrm{mg} \text { PO } 4 \mathrm{x} / \mathrm{d} \text { for } \\
7 \text { days or } \\
\text { Erythromycin ethylsuccinate } 800 \mathrm{mg} \text { PO } 4 \mathrm{x} / \mathrm{d} \text { for } 7 \text { days }\end{array}$ & None \\
\hline Epididymitis & $\begin{array}{l}\text { Ceftriaxone } 250 \mathrm{mg} \text { IM single dose + Doxycycline } 100 \mathrm{mg} \text { PO } 2 \mathrm{x} / \mathrm{d} \text { for } 10 \\
\text { days or } \\
\text { Ofloxacin } 300 \mathrm{mg} \text { PO } 2 \mathrm{x} / \mathrm{d} \text { for } 10 \text { days }\end{array}$ & None \\
\hline Bacterial vaginosis & $\begin{array}{l}\text { Metronidazole } 500 \mathrm{mg} \text { PO } 2 \mathrm{x} / \mathrm{d} \text { for } 7 \text { days or } \\
\text { Clindamycin cream } 2 \% \text {, one full applicator }(5 \mathrm{~g}) \text { intravaginal at bedtime for } \\
7 \text { days or } \\
\text { Metronidazole gel } 0.75 \% \text {, one full applicator }(5 \mathrm{~g}) \text { intravaginal } 2 \mathrm{x} / \mathrm{d} \text { for } 5 \\
\text { days }\end{array}$ & $\begin{array}{l}\text { Metronidazole } 2 \mathrm{~g} \text { PO single dose or } \\
\text { Clindamycin } 300 \mathrm{mg} \text { PO } 2 \mathrm{x} / \mathrm{d}\end{array}$ \\
\hline
\end{tabular}

Adapted from references $[5,12]$.

There are several challenges that face STI treatment in adolescents $[2,24]$. Most STI treatment infrastructure and services are tailored towards adults, hence adolescents who think they may have an STI often delay or do not seek treatment due to lack of adolescent-friendly services. The fear of disapproval of their sexual behavior by health workers, peers and parents is a major obstacle to treatment. Other obstacles include the lack of confidentiality, non-adherence to treatment, and financial limitations in meeting costs for transport, diagnosis and treatment [2,24]. Adolescent women may also be ignorant about STI symptoms and will oftentimes confuse normal and abnormal vaginal discharge. Others may be more concerned about pregnancy and menstrual problems than STIs, and therefore present late for treatment. For effective treatment, practitioners should be inquisitive about the adolescent patient's partner [5] because adolescents may be in denial, easily become irritated or even shocked that they have contracted an STI and therefore see no need to notify their partner [5]. However, sexual contact tracing among adolescents can be tricky as most adolescents with STIs do not want their parents to know [5]. In most adolescent STI treatment settings, parent notification remains a serious ethical challenge because it weighs against the ideals of confidentiality.

\section{Prevention}

STIs can be prevented by behavioural interventions [12] and increased awareness. Education on STIs can be done at home, school, and at the hospitals [5]. But education alone is not the panacea to STIs as it may not lead to behavioural changes that reduce the risk of STIs. Emphasis should be placed on the fact that adolescents will be able to recognize the STI symptoms, as well as to remember that many STIs are transmitted by asymptomatic partners. Health providers will need to focus on primary prevention (decreasing the number of new cases of STIs by avoiding exposure and preventing the infection through accurate information about STIs, postponing sexual involvement, encouraging consistent condom use, and development and implementation of appropriate vaccination approaches); secondary prevention through decreasing the number of existing cases via early detection and screening, especially of asymptomatic carriers, and treatment; and tertiary prevention which entails the minimization of STI sequelae [5]. WHO has devised a global strategy to combat STIs from 2006-2015 [4].

\section{CONCLUSION}

STIs present a notorious and real health burden on adolescents, especially among females in developing countries. Although adolescents share many health characteristics with adults, their STI problems may be different in many aspects. For this reason, the WHO recommends the improvement of existing guidelines and algorithms to enable health workers meet the special needs of adolescents. Effective preventive and treatment strategies that influence adolescent health-seeking behaviour could have long-lasting and positive effects on young people's sexual and reproductive lives. However, due to inadequate and lack of adolescent-friendly health services, many STIs in adolescents remain undetected and untreated. This is especially worrisome because many STIs are asymptomatic. Few countries have screening and reporting systems for STIs other than HIV, especially in adolescent populations. There is need to increase the capture of age- and gender-specific data among school-going and out-of-school adolescents. The World Health Organization and other development partners have put in place initiatives to improve STI diagnostics and adolescent health especially in resource-limited areas. In the early days of the HIV epidemic when antiretroviral treatment was unaffordable, treatment of STIs received a lot of attention because of its impact on AIDS.

Recently, the focus has shifted so much onto HIV treatment that research on STIs has lost momentum and funding. Lack of surveillance data could be sweeping the STI problem under the carpet.

\section{REFERENCES}

[1] WHO [World Health Organization]. The second decade: improving adolescent health and development. Geneva: WHO Adolescent Health and Development Programme (WHO/FRH/ADH/98.18), 1998. 
[2] Dehne KL, Riedner G. Sexually transmitted infections among adolescents: the need for adequate health care. Geneva: WHO 2005.

[3] UNFPA. State of world population, 2003. Available from: http://www.unfpa.org/swp/2003/english/ch3/index.htm

[4] WHO [World Health Organization]. Global strategy for the prevention and control of sexually transmitted infections: 2006-2015. Geneva: WHO 2007. Available from: http://www.who.int/reproductivehealth/publications/stisstrategy/stis_strategy.pdf [Retrieved: 21 April 2009].

[5] Hill YL, Biro FM. Adolescents and sexually transmitted infections. CME Feature 2009. Available from: http://www.hawaii.edu/hivandaids/ Sexually $\% 20$ Transmitted $\% 20$ Infections $\% 20 \mathrm{In} \% 20$ Adolescents $\% 20 \% 2$ 0\%20\%20A\%20Clinical\%20Challenge.pdf [Retrieved: 21 April 2009].

[6] Alan Guttmacher Institute. Sexually transmitted diseases hamper development efforts. Issues in Brief 1998 series no. 2. New York \& Washington: Alan Guttmacher Institute, 1998. Available from: http://www.guttmacher.org/pubs/ib_std.pdf [Retrieved: April 12, 2009].

[7] Mayaud P, Mabey D. Approaches to the control of sexually transmitted infections in developing countries: old problems and modern challenges. Sex Transm Infect 2004; 80: 174-82.

[8] CDC [Centers for Disease Control and Prevention], Division of STD Prevention. Sexually Transmitted Disease Surveillance 1999. Atlanta: Department of Health and Human Services, Centers for Disease Control and Prevention (CDC), 2000. Available from: http://www.cdc.gov/std/stats99/99PDF/99Section8.pdf [Retrieved: March 30, 2009].

[9] Yarber WL, Parrillo AV. Adolescents and sexually transmitted diseases. J Sch Health 1992; 62: 331-8.

[10] CDC [Centre for Disease Control and Prevention], Division for Sexually Transmitted Diseases. Tracking the hidden epidemic, trends in STDs in the United States, April 2000.

[11] Cates W, Pheeters MC. Adolescents and sexually transmitted diseases: current risks and future consequences. Paper prepared for the workshop on adolescent sexuality and reproductive health in developing Countries: trends and interventions. Washington, D.C.: National Research Council, March 25, 1997.

[12] Cheng SY, Lo KK. Sexually transmitted infections in adolescents. HK J Paediatr (New Series) 2002; 7: 76-84.

[13] Mwapasa V, Rogerson SJ, Kwiek JJ, et al. Maternal syphilis infection is associated with increased risk of mother-to-child transmission of HIV in Malawi. AIDS 2006; 20: 1869-77.

[14] Reitman DS. Adolescent medicine update: update on sexually transmitted diseases: gonorrhoea and Chlamydial infections, 2009; Available from: http://www.consultantlive.com/display/article/10162/ 10971 [Retrieved: April 12, 2009].

[15] Neinstein LS. Sexuality-sexually transmitted infections-overview (B3). adolescent health curriculum. Available from: http://www. usc.edu/student-affairs/Health_Center/adolhealth/content/b3stis1.html [Retrieved: April 12, 2009].

[16] Stanberry LR. The epidemiology of herpes simplex virus infection in adolescents. Herpes 1999; 6: 12-5.

[17] Abma JC, Sonenstein FL. Sexual activity and contraceptive practices among teenagers in the United States, 1988 and 1995. Vital Health Stat 2001;21: 1-79.

[18] Ethier KA, Kershaw T, Niccolai L, Lewis JB, Ickovics JR. Adolescent women underestimate their susceptibility to sexually transmitted infections. Sex Transm Infect 2003; 79: 408-11.

[19] Chinsembu KC, Siziya S, Rudatsikira E, Muula AS. Prevalence and social correlates of sexual intercourse among school-going adolescents in Namibia. SAHARA J 2008; 5: 129-35.

[20] Stanton BF, Fitzgerald AM, Li X, et al. HIV risk behaviours, intentions and perceptions among Namibian youth as assessed by a theory-based questionnaire. AIDS Educ Prev 1999; 11: 132-49.

[21] STD Surveillance. Special Focus Profiles, STDs in adolescents and young adults; 2003; 53-61; Available from: http://www.hawaii. edu/hivandaids/STDs_in_Adolescents_and_Young_Adults_2003.pdf [Retrieved: April 20, 2009].

[22] CDC [Centers for Disease Control and Prevention]. Availability of comprehensive adolescent health services. MMWR 1993; 42: 510-5.

[23] Brabin L. Providing accessible care for adolescents with sexually transmitted disease. Acta Trop 1996; 62: 209-16.

[24] WHO [World Health Organization] Youth friendly health services. Background paper for Technical Steering Committee Second Meeting. 29 May - 2 June, Geneva: WHO, Department of Child and Adolescent Health and Development, 2000.
[25] Grosskurth H, Mosha F, Todd J, et al. Impact of improved treatment of sexually transmitted diseases on HIV infection in rural Tanzania: randomised control trial. Lancet 1995; 346: 530-6.

[26] Taha TE, Dallabetta GA, Hoover DR, et al. Trends of HIV-1 and sexually transmitted diseases among pregnant and post-partum women in urban Malawi. AIDS 1998; 12: 197-203.

[27] Fortenberry JD. Sexually transmitted diseases in adolescents. Available from: http://www.update.com/patients/contents/topic.do?topickey= [Retrieved: April 12, 2009].

[28] Da Ros CT, Schmitt CD. Global epidemiology of sexually transmitted diseases. Asian J Androl 2008; 10: 110-4.

[29] Wentworth BB, Bonin P, Holmes KK, Gutman L, Wiesner P, Alexander ER. Isolation of viruses, bacteria and other organisms from venereal disease clinic patients: methodology and problems associated with multiple isolations. Health Lab Sci 1973; 10: 75-81.

[30] Trent M, Chung S, Clum G, et al. New sexually transmitted infections among adolescent girls infected with HIV. Sex Transm Infect 2007; 83:468-69; doi:10.1136/sti.2007.026161 [Cited: 15 Aug 2007]; Available from: http://www.sti.bmj.com

[31] Debattista J, Martin P, Jamieson J, et al. Detection of Chlamydia trachomatis in an Australian High School student population. Sex Transm Infect 2002; 78: 194-7.

[32] WHO [World Health Organization]. Sexually transmitted diseases diagnostics initiative (SDI). Available from: http://www.who.int/ std_diagnostics/; 2009 [Retrieved: 21 April 2009].

[33] Panchaud C, Susheela S, Feivelson D, Darroch JE. Sexually transmitted diseases among adolescents in developed countries. Fam Plann Perspect 2000; 32: 24-32.

[34] Cates W. Estimates of the incidence and prevalence of sexually transmitted diseases in the United States. Sex Transm Dis 1999; 26: S27.

[35] Institute of Medicine. The hidden epidemic: confronting sexually transmitted diseases. Washington, DC: National Academy Press 1997.

[36] CDC [Centre for Disease Control and Prevention], Department of Health and Human Services. 2008 National STD Prevention Conference, Chicago, March 10-13, 2008. Available from: http://www. cdc.gov/stdconference/

[37] Risser WL, Bortot AT, Benjamins LJ, et al. The epidemiology of sexually transmitted infections in adolescents. Semin Pediatr Infect Dis 2005; 16: 160-7.

[38] CDC [Centre for Disease Control and Prevention]. Sexually transmitted disease surveillance, 2001. Atlanta, G.A.: CDC, 2002 [Retrieved: 21 April 2009].

[39] Brabin L. Prevention of pelvic inflammatory disease: screening of high risk groups. In: Templeton A, Ed. The prevention of pelvic infection. London: RCOG Press 1996; pp. 160-80.

[40] CDC [Centre for Disease Control and Prevention]. Sexually transmitted diseases surveillance, 2004. Atlanta, G.A.: USA. Department of Health and Human Services, CDC, National Centre for HIV, STD and TB Prevention; 2005.

[41] Webster L, Berman SM, Greenspan JR. Surveillance for gonorrhoea and primary and secondary syphilis among adolescents, United States1981-1991. MMWR CDC Surveill Summ 1993; 42: 1-11.

[42] Wasserheit JN, Aral SO. The dynamic topology of sexually transmitted disease epidemics: implications for prevention strategies. J Infect Dis 1996; 174(Supp 12): S201-13.

[43] Ellis G, Grey A. Prevention of sexually transmitted infections (STIs): a review of reviews into the effectiveness of non-clinical interventions: evidence briefing 2004; Health Development Agency; Available from: www.hda.nhs.uk/evidence [Retrieved: April 12, 2009].

[44] White C, Wardropper AG. Genital herpes simplex infection in women. Clin Dermatol 1997; 15: 81-91.

[45] Brabin L. Sexually transmitted infections: issues in adolescent health and development. WHO Discussion Papers on Adolescence, Geneva: WHO 2004.

[46] UNAIDS, WHO [Joint United Nations Programme on HIV/AIDS, World Health Organization]. Sexually transmitted diseases: policies and principles for prevention and care. UNAIDS best practices collection: key material. Geneva: UNAIDS/WHO 1997.

[47] Lule G, Behets FM-T, Hoffman IF, et al. STD/ HIV control in Malawi and the search for affordable and efficient urethritis therapy: a first field evaluation. GUM 1994; 70: 384-8.

[48] Grosskurth H, Mayaud P, Mosha F, et al. Asymptomatic gonorrhoea and Chlamydia infections in rural Tanzanian men. BMJ 1996; 312: 277-80. 
[49] Brown A, Jejebhoy SJ, Shah I, Yount KM. Sexual relations among young people in developing countries: evidence from WHO case studies. Geneva: WHO 2001.

[50] Nessa K, Waris SA, Sultan Z, et al. Epimemiology and etiology of sexually transmitted infection among hotel-based sex workers in Dhaka, Bangladesh. J Clin Microbiol 2004; 42: 618-21.

[51] MacPhail CB, Williams G, Campbell C. Relative risk of HIV infection among young men and women in a South African township. Int J STD AIDS 2002; 13: 331-42.

[52] Larsen JV, Chapman JA, Armstrong A. Child sexual abuse in Kwa Zula-Natal, South Africa. Trans R Soc Trop Med Hyg 1998; 92: 262-4.

[53] Institut de Recherche et des Etudes des Comportements. Peer education as a strategy to increase contraceptive prevalence and reduce the rate of STIs/HIV among adolescents in Cameroon. A report based on a study funded by USAID HRN-A-00-98-00012-00 and Population Council subproject A100.32A, 2002.

[54] Chamilla G, Mbwana J, Mhalu F, et al. Patterns of sexually transmitted infections in adolescents and youth in Dar es Salaam, Tanzania. BMC Infect Dis 2006; 6: 22. doi:10.1186/186/1471-23334-6-22. Available from: http://www.biomedcentral.com/1471-2334/6/22 [Retrieved: 21 April 2009].

[55] Urassa W, Moshiro C, Chalamilla G, Mhalu F, Sandstrom E. Risky sexual practices among youth attending a sexually transmitted infection clinic in Dar es Salaam, Tanzania. BMC Infect Dis 2008; 8: 159. doi:10.1186/1471-2334-8-159. Available from: http://www.bio medcentral.com/147-2334/147-2334/8/159 [Retrieved: 21 April 2009].

[56] Blankhart D, Muller O, Gresenguet G, Weis P. Sexually transmitted infections in young pregnant women in Bangui, Central African Republic. Int J STD AIDS 1999; 10: 609-14.

[57] Mwakagile D, Swai AB, Sandström E, Urassa E, Biberfeld G, Mhalu FS. High frequency of sexually transmitted diseases among pregnant women in Dar es Salaam, Tanzania: need for intervention. East Afr Med J 1996; 73: 675-8.

[58] Behets FMT, Williams Y, Brathwaite A, et al. Management of vaginal discharge in women treated at a Jamaican sexually transmitted disease clinic: use of diagnostic algorithms versus laboratory testing. Clin Infect Dis 1995; 21: 1450-5.

[59] Vuylsteke B, Laga M, Alary M, et al. Clinical algorithms for the screening of women for gonococcal and Chlamydial infection: evaluation of pregnant women and prostitutes in Zaire. Clin Infect Dis 1993; 17: 82-8.

[60] Harms G, Radebe F, Iyambo SN, Fehler HG, Ballard RC, Corea A. Perceptions and patterns of reproductive tract infections in a young rural population in North-West Namibia. Int J STD AIDS 1998; 9: 744-50.

[61] Mufune P, Kaundjua MB, Indongo N, Nickanor, Mchombu K. Baseline survey on sexual and reproductive health and HIV/AIDS among adolescent and youth. Windhoek: UNFPA/UNAM 2002.

[62] Diallo MO, Ghys PD, Vuylsteke B, et al. Evaluation of simple diagnostic algorithms for Neisseria gonorrhoea and Chlamydia trachomatis cervical infections in female sex workers in Abidjan, Côte d'Ivoire. Sex Transm Infect 1998; 74(Suppl): S106-11.

[63] Miranda AE, Szwardcwald CL, Peres RL, Page-Shafer K. Prevalence and risk behaviors for Chlamydial infection in a population-based study of female adolescents in Brazil. Sex Transm Dis 2004; 31: 542-6.

[64] Fioravante FC, Alves MF, Guimaraes EM, Turchi MD, Freitas HA, Domingos LT. Prevalence of Chlamydia trachomatis in asymptomatic Brazilian military conscripts. Sex Transm Dis 2005; 32: 165-9.

[65] Araujo RS, Guimaraes EM, Alves MF, et al. Prevalence and risk factors for Chlamydia trachomatis infection in adolescent females and young women in central Brazil. Eur J Clin Microbiol Infect Dis 2006; 25: 397-400.

[66] Anonymous. RTIs/STIs among special populations, 2009. Available from: http://mohfw.nic.in/NRHM/RTI_PDF/Chapter\%206.pdf [Retrieved: April 21, 2009].

[67] Williams OE. Sexually transmitted diseases. In: Garden AS, Ed. Paediatric and adolescent gynaecology. London, Arnold 1998; pp. 16783 .
[68] Hillis SD, Nakashima A, Marchbanks PA, Addiss DG, Davis JP. Risk factors for recurrent Chlamydia trachomatis infections in women. Am J Obstet Gynecol 1994; 170: 801-6.

[69] Brabin L. Tailoring clinical management practices to meet the special needs of adolescents: Sexually transmitted infections. Discussion paper prepared for the Adolescent Health and Development Programme, Family and Reproductive Health. Geneva: WHO 1998.

[70] Chinsembu KC, Matondo P, Banda SS. Sexually transmitted diseases: a training manual for health workers. STD/Clinical Care Unit, AIDS/STD/TB/Leprosy Programme, Ministry of Health, Lusaka 1997.

[71] Matondo P, Sandala LM. In: Matondo P, Chinsembu KC, Kapembwa MS, Eds. Sexually transmitted disease syndromes: a text and atlas. Lusaka, Ministry of Health, Government of the Republic of Zambia/Xpress Yourself 1998; pp. 64-7.

[72] Gevelber MA, Biro FM. Adolescents and sexually transmitted diseases. Pediatr Clin North Am 1999; 46: 747-66.

[73] Fox KK, Knapp JS, Holmes KK, et al. Antimicrobial resistance in Neisseria gonorrhoeae in the United States, 1988-1994. J Infect Dis 1997; 175: 1396- 403 .

[74] Weisntock H, Berman S, Cates W, Jr. Sexually transmitted diseases among American youth: incidence and prevalence estimates, 2000. Perspt Sex Rep Health 2004; 36: 6-10.

[75] Forhan SE, Gottlieb SL, Sternberg MR, et al. Prevalence of sexually transmitted infections and bacterial vaginosis among female adolescents in the United States: Data from the National and Nutritional Examination Survey (NHANES) 2003-2004. Available from: http://www.cdc.gov/stdconference/2008/media/summaries-11march20 08.htm\#tues1 [Retrieved: April 12, 2009].

[76] Fortenberry JD, Brizendine EJ, Katz BP, Wools KK, Blythe MJ, Orr DP. Subsequent sexually transmitted infections among adolescent women with genital infection due to Chlamydia trachomatis, Neisseria gonorrhoeae, or Trichomonas vaginalis. Sex Transm Dis 1999; 26: 2632.

[77] Hoff T, Greene L, Davis J. National survey of adolescents and young adults: sexual health knowledge, attitudes and experiences. Available from: http://www.kff.org/youthhivstds/upload/National-Survey-Of-Ado lescents-and-Young-Adults.pdf; 2003 [Retrieved: 21 April 2009].

[78] CDC [Centers for Disease Control and Prevention]. Youth risk behavior surveillance- United States. MMWR Morb Mortal Wkly Rep 1999b; 49: 1-96.

[79] Burstein GR, Gaydos CA, Diener-West M, Howell MR, Zenilman JM, Quinn TC. Incident Chlamydia trachomatis infections among inner-city adolescent females. JAMA 1998; 280: 521-6.

[80] CDC. STD Surveillance 2006. Centres for Disease Control and Prevention. Available from: http://www.cdc.gov/std/stats/ [Retrieved: April 12, 2009].

[81] Flemming DT, McQuillian GM, Johnson RE, et al. Herpes simplex virus type 2 in the U.S., 1976 to 1994. N Engl J Med 1997; 337: 110511.

[82] Rosenthal SL, Stanberry LR, Biro FM, et al. Seroprevalence of herpes simplex virus types 1 and 2 and cytomegalovirus in adolescents. Clin Infect Dis 1997; 24: 135-9.

[83] Obasi A, Mosha F, Quigley M, et al. Antibody to herpes simplex virus type 2 as a marker of sexual risk behavior in rural Tanzania. J Infect Dis 1999; 179: 16-24.

[84] Wagner HU, Van Dyck E, Roggen E, et al. Seroprevalence and incidence of sexually transmitted diseases in a rural Ugandan population. Int J STD AIDS 1994; 5: 332-7.

[85] De la Court A, Ikedugwu A, Agbaje O, Obunge OK, Briggs ND, Brabin L. Screening for sexually transmitted infections in adolescent college girls in Port Harcourt, Nigeria: search for a simple screening test for STDs. Abstract, 2nd European Congress on Tropical Medicine; Sep 14-18; 1998, Liverpool, UK.

[86] ZDHS [Zambia Demographic and Health Survey]. Zambia Demographic Health Survey. Lusaka: Central Statistical Office 1996. 